\title{
Aplikasi Pompa Air Tenaga Matahari untuk Petani Palawija di Kabupaten Takalar
}

\author{
Jalaluddin $^{1 *}$, Rustan Tarakka ${ }^{1}$, Andi Nurfaidah Rahman ${ }^{2}$, Andi Amijoyo Mochtar ${ }^{1}$, Syahrir Arief $^{1}$ \\ ${ }^{1}$ Departemen Teknik Mesin, Fakultas Teknik, Universitas Hasanuddin \\ ${ }^{2}$ Departemen Teknologi Pertanian, Fakultas Pertanian, Universitas Hasanuddin \\ jalaluddin_had@yahoo.com ${ }^{1 *}$
}

\begin{abstract}
Abstrak
Kabupaten Takalar merupakan salah satu daerah di provinsi Sulawesi Selatan dengan produksi jagung dan cabai rawit yang besar. Tanaman palawija ini membutuhkan sinar matahari langsung dan air yang tidak terlalu banyak sehingga penyediaan air sangat cocok dengan pemanfaatan pompa air tenaga matahari dari sumur dangkal di areal persawahan. Pemanfaatan energi matahari yang bebas polusi dan berlimpah, dapat diperbaharui serta tidak ada habisnya sangat potensial karena daerah ini mempunyai tingkat penyinaran matahari yang tinggi. Penggunaan pompa tenaga matahari untuk keperluan pengairan pada tanaman palawija akan memberi manfaat kepada para petani dengan mengurangi biaya yang harus dikeluarkan untuk penyediaan pengairan dan menjamin ketersediaan air untuk kebutuhan tanaman. Prototipe dari pompa air tenaga matahari dibuat dan telah digunakan di areal persawahan petani sebagai percontohan teknologi. Petani palawija telah dilatih terkait operasional dan perawatan pompa tenaga matahari tersebut. Implementasi dari kegiatan pengabdian ini dilaksanakan pada tanggal 20 Oktober 2018 meliputi pelatihan masyarakat dan percontohan aplikasi teknologi yang meliputi : 1) transfer teknologi ke masyarakat dilakukan untuk peningkatan pemahaman terkait pompa air tenaga matahari dan penggunaannya; 2) 1 unit pompa air tenaga matahari dipasang di areal persawahan tanaman palawija. Kegiatan ini telah membantu mempermudah masyarakat dalam memanfaatkan sumber energi terbarukan dalam pemanfaatan pompa air tenaga matahari untuk pengairan tanaman palawija. Hal ini juga akan berpengaruh dalam meningkatkan produktivitas petani palawija dengan pengurangan biaya penyedian air serta meningkatkan pendapatan petani. Hasil pengujian lapangan menunjukkan intensitas matahari rata-rata pada saat pengujian sekitar $874 \mathrm{~W} / \mathrm{m}^{2}$ sedangkan debit air pompa rata-rata sekitar $3.8 \mathrm{~L} / \mathrm{menit}$. Pompa air tenaga matahari dapat mengisi air pada tangki berkapasitas 650 liter dengan waktu pengisian sekitar 2.8 jam.
\end{abstract}

Kata Kunci: Pemberdayaan Masyarakat; Transfer Teknologi; Pompa Air Tenaga Matahari; Petani Palawija.

\section{Pendahuluan}

Kabupaten Takalar berada antara $5^{\circ} 3^{\prime}-5^{\circ} 38^{\prime}$ lintang Selatan dan $119^{\circ} 22^{\prime}-119^{\circ} 39^{\prime}$ bujur Timur dengan batas wilayah selat Makassar di sebelah Barat, Kabupaten Jeneponto dan Kabupaten Gowa di sebelah Timur, Kabupaten Gowa di sebelah Utara dan laut Flores di sebelah Selatan. Daerah ini memiliki tingkat penyinaran matahari yang tinggi dan potensi yang sangat besar untuk pemanfaatan sumber energi matahari. Sumber energi matahari dapat diaplikasikan secara luas untuk pertanian seperti pengeringan hasil-hasil pertanian dan pemanfaatan lainnya. Salah satu aplikasi yang dapat dilakukan adalah dengan pemanfaatan pompa air tenaga matahari untuk pengairan tanaman palawija. Tanaman Palawija yang banyak ditanam di Kabupaten Takalar antara lain jagung, cabai rawit, kacang hijau, dan lain-lain. Tanaman ini membutuhkan sinar matahari langsung dan air yang tidak terlalu banyak sehingga penyediaan air sangat cocok dengan pemanfaatan pompa air tenaga matahari dari sumur dangkal di areal persawahan. Jagung dan cabe rawit merupakan tanaman andalan di Kabupaten Takalar. Beberapa daerah di Kabupaten Takalar merupakan daerah produksi jagung dan pusat areal budidaya cabai rawit.

Pemanfaatan energi matahari mendapat perhatian yang sangat besar sekarang ini dengan berbagai macam teknologi pemanfaatan. Teknologi sel PV sebagai sumber energi listrik telah banyak digunakan untuk penerangan dan berbagai peralatan. Kincir aerator dengan sumber energi listrik 
melalui teknologi sel PV pada tambak udang telah diaplikasikan (Jalaluddin dkk, 2015). Pemanfaatan lainnya yang telah digunakan antara lain: penggerak pompa rumahan (Arfandy dkk, 2016); pompa air pada tambak udang (Jalaluddin dkk, 2018). Selain itu, beberapa studi tentang analisis unjuk kerja sel PV juga telah dilakukan seperti: sel PV dengan penggunaan air pendingin di bawah panel (Jalaluddin dkk, 2016) dan sel PV dengan pengarah matahari (Jalaluddin dan Mire, 2017). Selain itu, semakin banyak produk pendukung dalam pemanfaatan energi matahari yang tersedia dipasaran. Hal ini membutuhkan transfer ilmu dan implementasi teknologi ke masyarakat dalam hal pemanfaatan energi matahari untuk mendukung pemanfaatan energi terbarukan dan dalam upaya mendukung penghematan energi secara nasional. Salah satu pemanfaatan sumber energi ini yang dapat dilakukan di Kabupaten Takalar adalah pemanfaatan pompa air tenaga matahari untuk pengairan tanaman palawija.

Pemerintah Kabupaten Takalar telah berusaha untuk mewujudkan daerahnya sebagai penghasil jagung terbesar di Sulawesi Selatan. Selain jagung, Kabupaten Takalar merupakan salah satu daerah yang dengan produksi cabai rawit yang besar. Kecamatan Pattalassang, Kecamatan Sanrobone, dan Kecamatan Mappakasunggu merupakan pusat areal budidaya cabai rawit di Kabupaten Takalar. Lahan pertanian jagung dan cabai rawit dapat dilihat pada gambar 1.

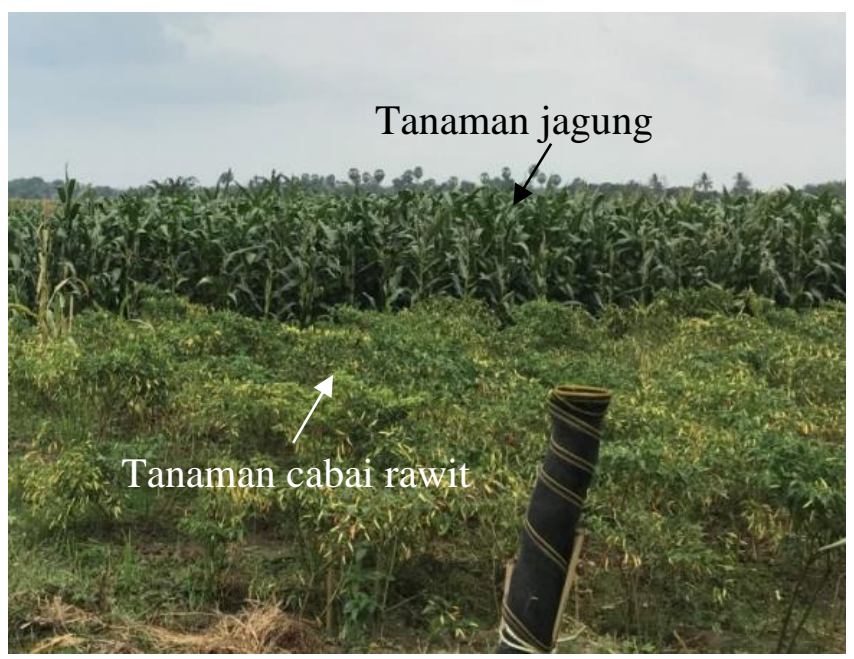

Gambar 1. Lahan Pertanian Jagung dan Cabai Rawit di Kabupaten Takalar

Beberapa persoalan yang dihadapi oleh petani tanaman palawija antara lain fluktuasi harga yang kadang-kadang merugikan petani serta persoalan teknis terkait penyediaan pengairan. Pengairan tanaman palawija dapat dilakukan dengan menggunakan sumber air dari sumur yang dibuat di areal persawahan. Pengairan tanaman jagung dan cabai rawit untuk penanaman di areal persawahan adalah sistem penggenangan (irigasi parit) dimana bagian yang digenangi air adalah bagian parit saja. Untuk mengantisipasi penyediaan air, petani membuat sumur di sekitar areal persawahan sebagai tempat mengambil air yang akan digunakan untuk menyiram tanaman palawija. Pemompaan air secara konvensional dengan menggunakan pompa berbahan bakar minyak umumnya dilakukan sekarang ini. Penggunaan pompa ini mengakibatkan masih mahalnya biaya yang harus dikeluarkan untuk penyediaan air tersebut. Selain itu, penggunaan bahan bakar fosil yg digunakan selama ini juga merusak lingkungan dengan pemanasan global. Pemanfaatan sumber energi terbarukan telah digalakkan oleh pemerintah sekarang ini. Penggunaan pompa tenaga matahari untuk keperluan pengairan pada tanaman palawija akan memberi manfaat kepada 
para petani dengan mengurangi biaya yang harus dikeluarkan untuk penyediaan pengairan dan menjamin ketersediaan air untuk kebutuhan tanaman.

Target luaran dari kegiatan pengabdian ini adalah aplikasi pompa air tenaga matahari untuk penyediaan pengairan tanaman palawija di Kabupaten Takalar. 1 unit pompa air tenaga matahari akan diaplikasikan untuk pengairan tanaman palawija. Petani palawija akan dilatih dalam mengoperasikan dan perawatan pompa air tenaga matahari tersebut. Implementasi pompa air tenaga matahari untuk penyedian pengairan palawija diharapkan dapat meningkatkan produktivitas petani palawija di Kabupaten Takalar.

\section{Pompa Air Tenaga Matahari}

Skema instalasi pompa air tenaga matahari dapat dilihat pada gambar 2a. Air dipompa dari sumur dengan menggunakan pompa celup. Daya penggerak dari pompa berasal dari energi matahari melalui sel photovoltaik (PV). Selanjutnya, air ditampung pada tangki penyimpanan air. Adapun prototipe dari pompa air tenaga matahari dapat dilihat pada gambar $2 \mathrm{~b}$.

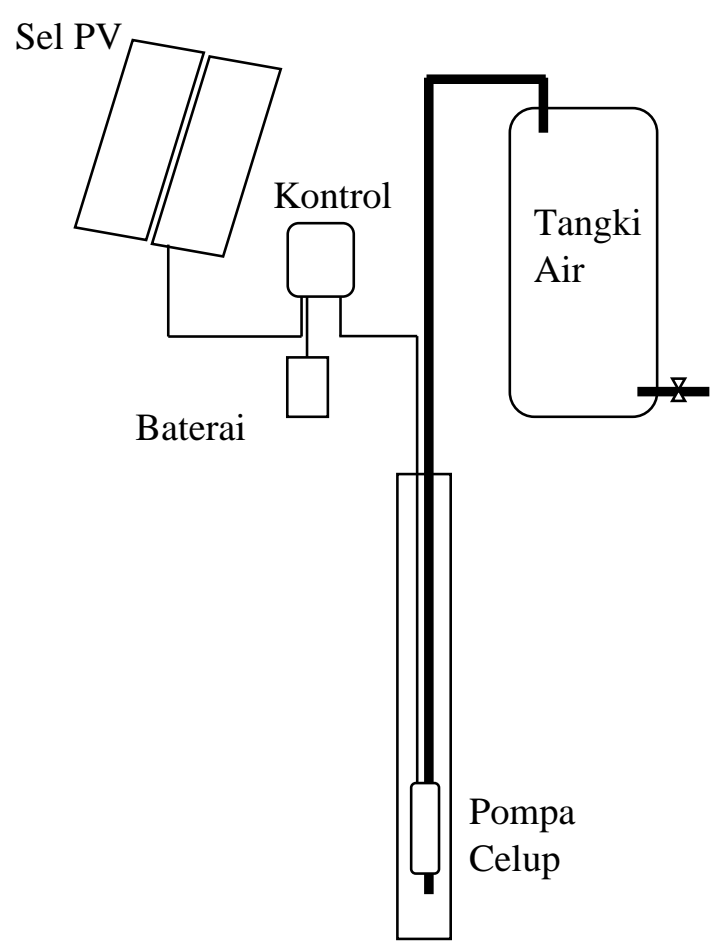

a) Skema instalasi

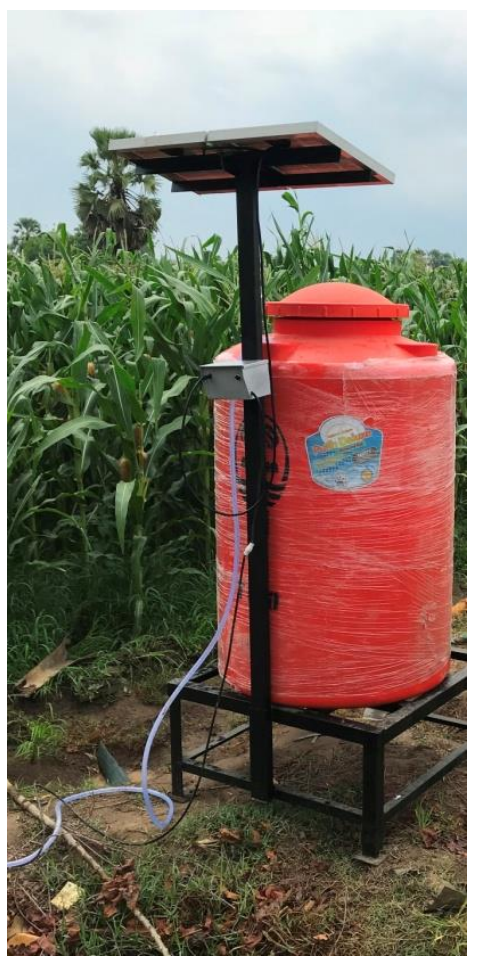

b) Prototipe pompa air tenaga matahari

Gambar 2. Pompa Air Tenaga Matahari 


\section{Metode Pelaksanaan}

Pemberdayaan masyarakat dengan implementasi teknologi energi terbarukan berupa aplikasi pompa air tenaga matahari untuk mengatasi masalah pengairan tanaman palawija dilakukan melalui transfer teknologi ke masyarakat untuk peningkatan pemahaman terkait pompa air tenaga matahari dan keterampilan dalam operasional serta perawatan pompa tersebut. Transfer teknologi ke masyarakat meliputi: pelatihan intensif, perakitan 1 unit peralatan pompa air tenaga matahari dan aplikasi pada pengairan tanaman palawija di areal persawahan sebagai percontohan teknologi. Pelatihan intensif kepada masyarakat diikuti oleh sekitar 20 orang petani palawija. Selanjutnya, implementasi teknologi energi terbarukan dilakukan dengan pemasangan 1 unit peralatan pompa air tenaga matahari untuk pengairan tanaman palawija di areal persawahan.

\section{Hasil dan Diskusi}

\subsection{Rancang Bangun Pompa Air Tenaga Matahari}

Rancang bangun pompa air tenaga matahari dilakukan di Laboratorium Energi Terbarukan Departemen Teknik Mesin Universitas Hasanuddin seperti terlihat pada gambar 3.
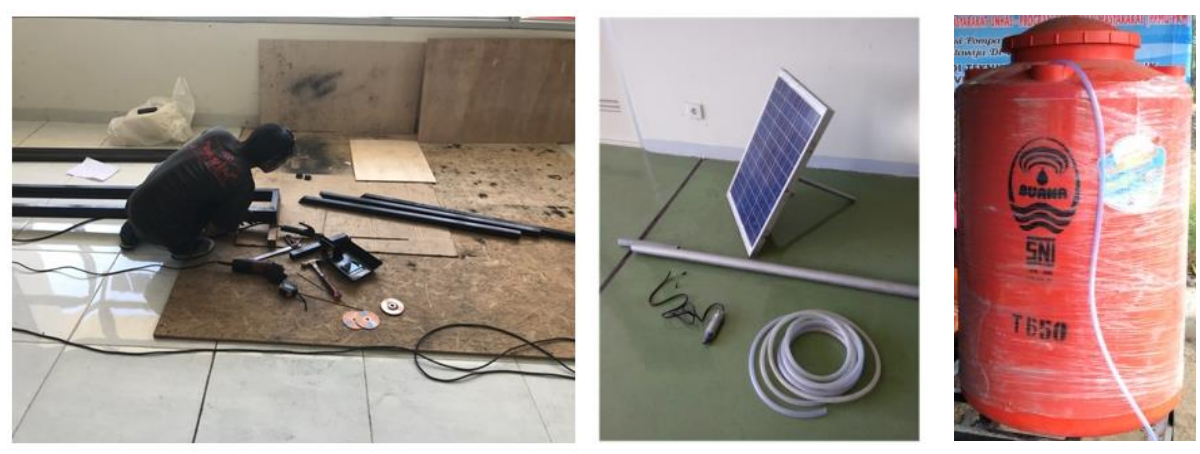

Gambar 3. Rancang Bangun Pompa Air Tenaga Matahari

\subsection{Pelatihan Masyarakat dan Pemasangan di Areal Persawahan Petani}

A. Pelatihan Masyarakat

Untuk memberi pengetahuan tentang pompa air tenaga matahari kepada masyarakat, pelatihan dilakukan di tempat mitra dengan melibatkan sekitar 20 orang petani palawija di Biring Balang Kabupaten Takalar. Pelatihan diawali dengan memperkenalkan komponen-komponen dari pompa air tenaga matahari antara lain : 1) sel PV ;2) sistem kontrol dan baterai ; 3) pompa celup dan 4) tangki air seperti terlihat pada gambar 4 . Sel PV yang digunakan berkapasitas 30 Watt yang terdiri dari 2 unit berkapasitas masing-masing 15 Watt. Pompa yang digunakan adalah 2 unit pompa 12 volt yang dipasang secara paralel. Tangki air yang digunakan berkapasitas 650 Liter. Selanjutnya, perakitan pompa air tenaga matahari dilakukan secara bersama-sama dengan masyarakat seperti terlihat pada Gambar 5. 

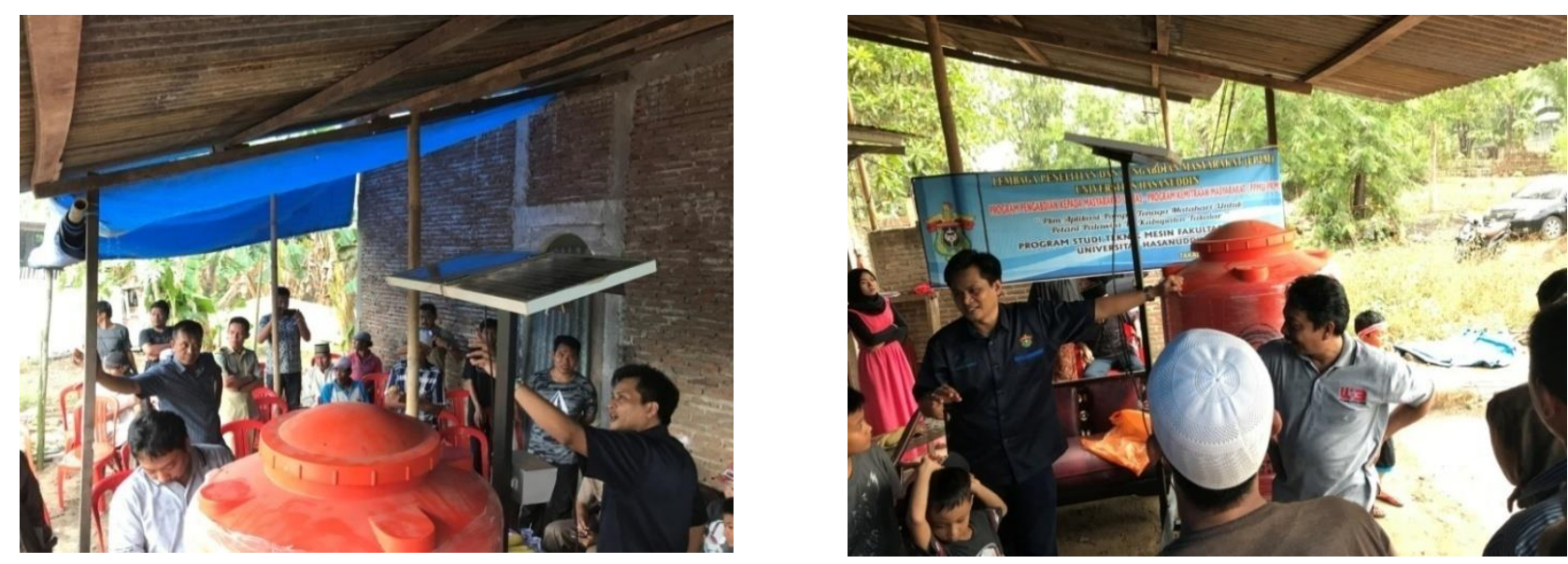

Gambar 4. Pelatihan Masyarakat

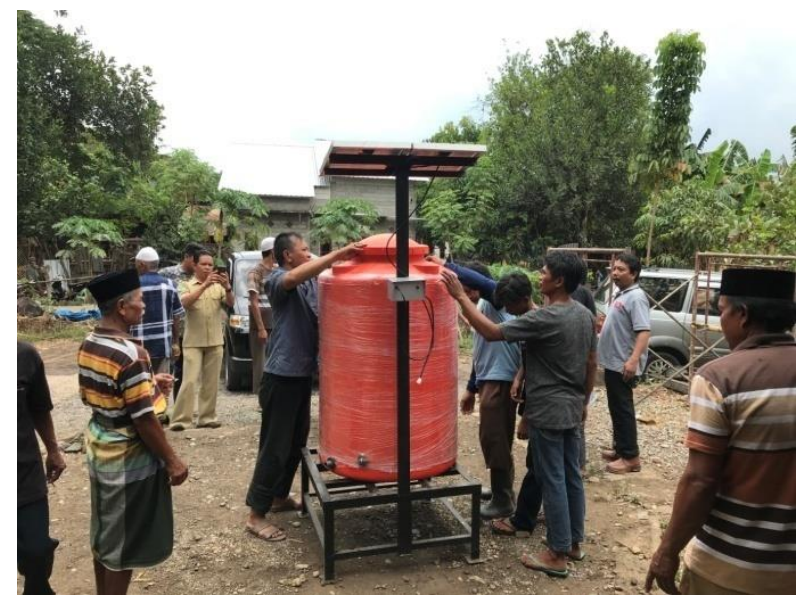

Gambar 5. Perakitan Pompa Air Tenaga Matahari

Sosialisasi dan pembekalan keterampilan kepada petani dalam pemanfaatan sumber energi matahari serta aplikasi teknologi pemanfaatan merupakan faktor utama keberhasilan pemanfaatan sumber energi ini di masyarakat. Pelatihan operasional pompa air tenaga matahari dilakukan dengan menjalankan pompa tesebut seperti terlihat pada gambar 6. Masyarakat dibimbing untuk dapat menjalankan pompa tersebut. Sumber energi listrik yang menjalankan pompa berasal dari energi matahari melalui sel PV. Energi listrik tersebut ditampung pada baterai dan selanjutnya, digunakan untuk menjalankan pompa air. Energi listrik yang tersedia pada baterai perlu dijaga dan diperhatikan ketersediannya sebelum menjalankan pompa air. Pompa air dapat dijalankan pada saat energi matahari tersedia sehingga baterai selalu terisi selama pompa air dijalankan. 

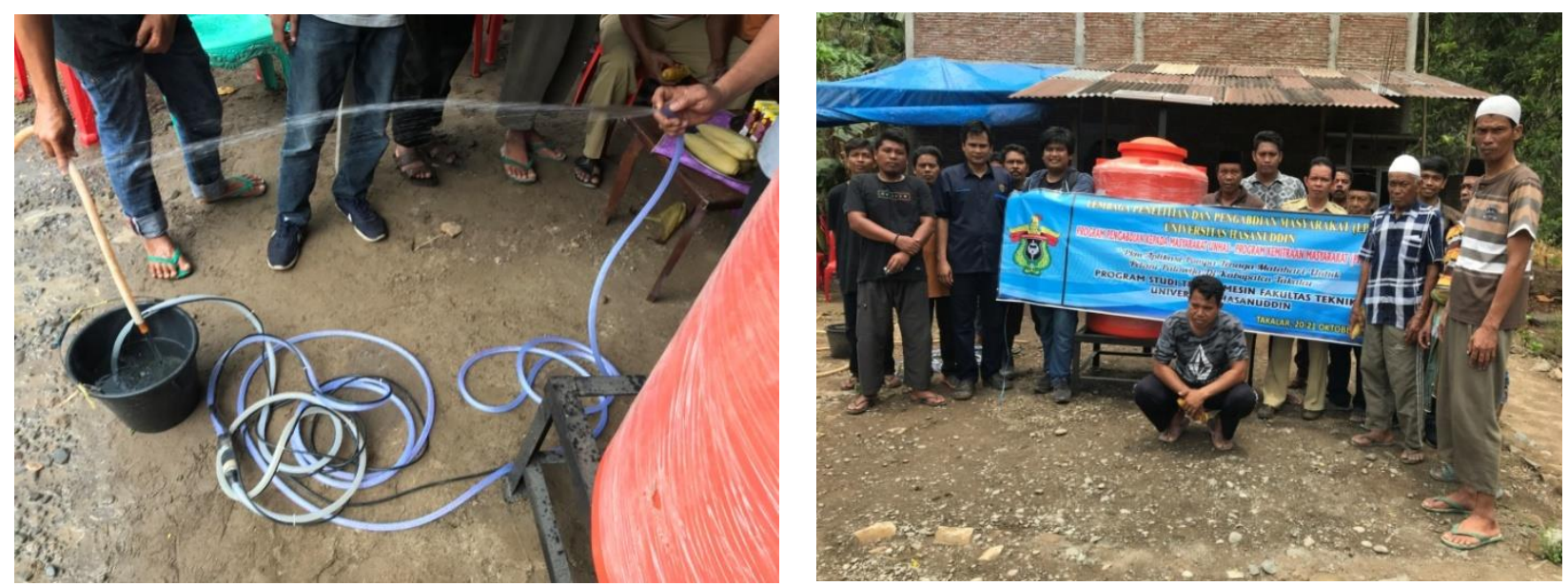

Gambar 6. Pelatihan Operasional Pompa Air Tenaga Matahari

\section{B. Pemasangan Pompa di Areal Persawahan Petani}

Pemasangan pompa air tenaga matahari dilakukan di areal persawahan petani seperti terlihat pada gambar 7. Setelah pemasangan pompa di areal persawahan, pengujian lapangan terhadap pompa air dilakukan untuk mengetahui kapasitas aktualnya. Hasil pengujian ini berupa data intensitas matahari $\left(\mathrm{W} / \mathrm{m}^{2}\right)$ dan debit air (L/menit) seperti terlihat pada gambar 8 . Intensitas matahari ratarata pada saat pengujian sekitar $874 \mathrm{~W} / \mathrm{m}^{2}$ sedangkan debit air pompa rata-rata sekitar $3.8 \mathrm{~L} /$ menit. Hal ini menunjukkan bahwa untuk mengisi tangki air berkapasitas 650 liter diperlukan waktu sekitar 2.8 jam. Selanjutnya, air yang sudah ditampung dapat digunakan untuk pengairan tanaman palawija.
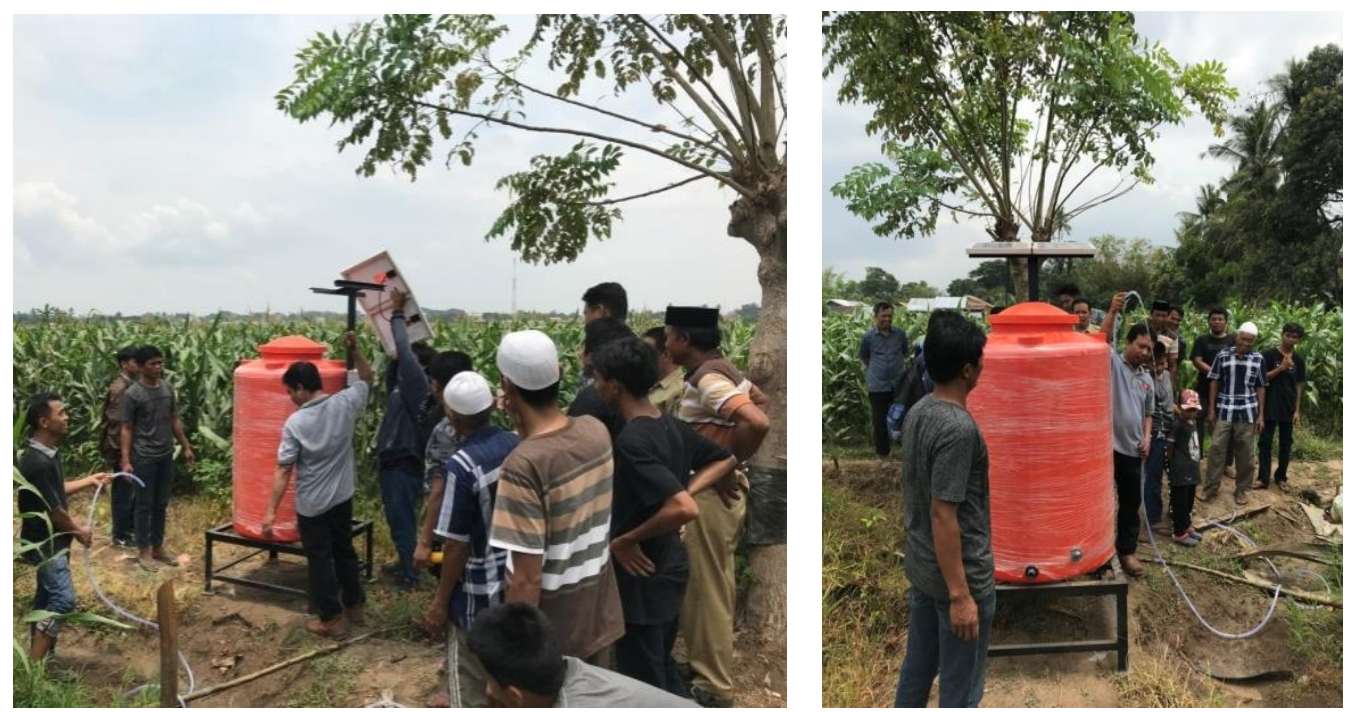

Gambar 7. Pemasangan Pompa Air Tenaga Matahari di Areal Persawahan Petani 


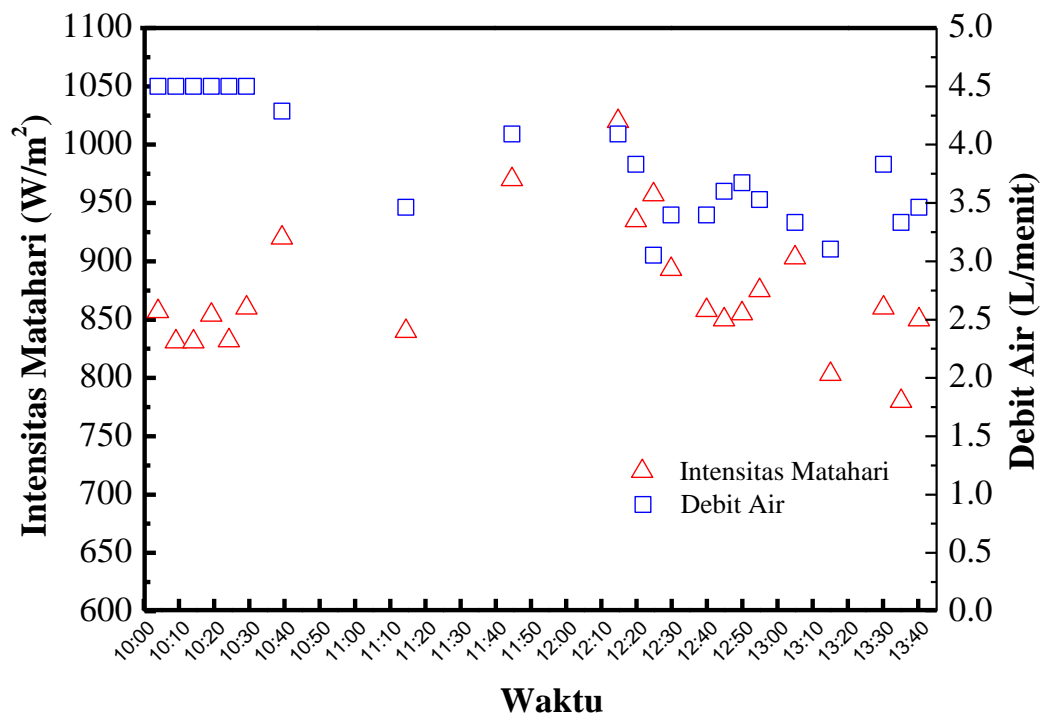

Gambar 8. Intensitas Matahari dan Debit Air Terhadap Waktu Pengujian

Kegiatan pengabdian ini mendapatkan respon yang sangat positif dari masyarakat dan pemerintah setempat karena telah memperkenalkan teknologi energi matahari. Penerapan pompa air tenaga matahari untuk pengairan tanaman palawija telah berhasil dilakukan. Dampak yang diperoleh adalah sebagai berikut : 1) peningkatan pengetahuan masyarakat petani palawija dalam penerapan pompa air tenaga matahari yang menggunakan sumber energi matahari yang tersedia secara luas, 2) ketertarikan masyarakat dalam aplikasi teknologi energi terbarukan seperti energi matahari, 3) pembuatan prototipe pompa air tenaga matahari di areal persawahan petani palawija sebagai percontohan teknologi.

\section{Kesimpulan}

Kegiatan pengabdian masyarakat berupa aplikasi pompa air tenaga matahari untuk petani palawija di Kabupaten Takalar telah dilakukan. Pelatihan untuk memberi pengetahuan tentang operasional dan perawatan pompa air tenaga matahari kepada masyarakat juga telah dilakukan dengan melibatkan sekitar 20 orang petani palawija. Selanjutnya, 1 unit pompa air tenaga matahari telah terpasang di areal persawahan petani palawija sebagai percontohan teknologi. Aplikasi pompa air tenaga matahari ini telah membantu masyarakat petani palawija dalam penyedian air untuk keperluan pengairan tanaman palawija secara gratis dengan menggunakan tenaga matahari. Pompa air tenaga matahari dapat mengisi air pada tangki berkapasitas 650 liter dengan waktu pengisian sekitar 2.8 jam.

\section{Ucapan Terima Kasih}

Ucapan terima kasih disampaikan kepada Lembaga Penelitian dan Pengabdian Masyarakat (LP2M) Universitas Hasanuddin atas dukungan dananya dalam pelaksanaan kegiatan pengabdian masyarakat ini. 


\section{Daftar Pustaka}

Jalaluddin, Jalil, A. R., Tarakka, R., Wardi, (2105). Pemberdayaan Masyarakat dengan Pemanfaatan Sumber Energi Terbarukan pada Tambak Udang, Agrokreatif Jurnal Ilmiah Pengabdian kepada Masyarakat, November 2015, Vol 1 (2): 136-141, ISSN 2460-8572, EISSN 2461-095X.

Jalaluddin, Himran, S., Arief, S., Khalik, A., (2016). Studi Eksperimental Performansi Modul Photovoltaik dengan Pendinginan Air, Prosiding Seminar Nasional Tahunan Teknik Mesin XV (SNTTM XV). Bandung 5 - 7 Oktober 2016.

Jalaluddin, Mire, B., (2017). Performansi Aktual Modul Photovoltaik dengan Pengarah Matahari, Jurnal Teknik Mesin Indonesia, Vol. 12 (2): 98-101.

Jalaluddin, Jalil, A. R., Tarakka, R., Wardi, (2018). Implementasi Pompa Air pada Tambak Udang dengan Pemanfaatan Sumber Energi Terbarukan, Jurnal Teknologi Terapan untuk Pengabdian Masyarakat, Vol 1 (1): 23-32.

Arfandy, R., Arif, E., Jalaluddin, (2016). Pemanfaatan Energi Matahari Sebagai Penggerak Pompa Rumahan, Prosiding Seminar Nasional ke 3 Rekayasa Material, Sistem manufaktur dan Energi. Gowa, 16 - 17 November 2016. 